\title{
MINAS E A IMPOSIÇÃO DO ESTADO NO BRASIL.
}

\author{
FRANCISCO IGLESIAS \\ da Universidade Federal de Minas Gerais.
}

O setecentos tem na História do Brasil importância especial do ângulo político. Se o século XVI foi o começo da revelação do território e do funcionamento do aparelho administrativo, da exploração econômica que vai da simples coleta à grande lavoura, para a exportação - típico da estrutura colonial —, com base no escravo e latifúndio, o seguinte continua e amplia o processo, iniciando a conquista do interior. Supera-se o limite fixado, com a anexação de amplas faixas que vão configurar a fisionomia que o Brasil tem hoje. Verificam-se as mais sérias lutas com o estrangeiro.

E no século XVIII que se define com rigor a administração porunguesa, como o fortalecimento do Estado, antes dividido e fragil; que se garante a posse do território, com os Tratados entre as duas Metrópoles - Espanha e Portugal; que se caracterizam as diferentes áreas - Norte, Nordeste, Centro, Sul, Oeste; começa, ainda que tímida, a comunicação entre algumas unidades, no primeiro momento de integração; embora mantida a característica colonial da economia, há princípio de mercado interno, com certo comércio entre as partes; que se esboça uma consciência nacional - se antes houve lutas contra pretensões estrangeiras, eram de portugueses e brasileiros contra o invasor, enquanto agora há luta de brasileiro contra português (antes menos comum), início da consciência emancipadora que culmina com a separação no século seguinte, como se vê em movimentos que se verificam em vários pontos; o sentido da terra aparece nas primeiras criações artísticas denunciadoras de peculiaridade nativa, sensivel nas artes plásticas, literatura e música.

Ao longo do terceiro século o pais amadurece, começa a definir o que é típico de sua fisionomia, de modo não só a criar uma cultura como a preparar a separação. E claro que é ainda tímido o que se verifica: continua bem português, sofrendo influência do dominador em todas as suas expressões, seja na política, na forma de vida, nos costumes, na arte, mas se denunciam peculiaridades, princípios de cul- 
tura que vai florescer depois, diferenciada da que lhe deu origem. Mais: se não se chega à consciência nacional, é que as điferentes partes mantem seus traços, como se nota mesmo em 1822, quando a Independência é feita em nome do Brasil, mas o que há são núcleos de frágil ligação - o maior esforço do administrador, nas décadas de vinte e trinta, é consolidar em unidade as várias regiões. No decurso do setecentos há aspirações emancipadoras de áreas, pela hostilidade ao dominador, mas não consciência nacional, idéia de Brasil. Em síntese do que havia no princípio do século XIX, Capistrano de Abreu viu

"cinco grupos etnográficos (..) sentindo pelo português aversão ou desprezo, não se prezando, porem, uns aos outros de modo particular".

O que se tem de creditar ao terceiro século é a consolidação desse sentimento de hostilidade, que vai ser o dado principal para a separação da Metrópole. Para o historiador, portanto, trata-se de periodo que se impõe - auge do sistema colonial e começo de desagregação, evidente nas últimas décadas. E o fim de uma época e o anúncio de outra, em mudança que se verifica logo no século XIX.

Neste breve ensaio não se pretende tratar de um aspecto, mas realçar a novidade das instituições políticas, com seu fortalecimento ao longo de cem anos, na caracterização do que foi o Estado. Pretende-se tambem explicar o fato pela existência de eixo em torno do qual gira o administrador, que são as minas de ouro, que condicionam direta ou indiretamente o período. Esse eixo é um dos responsáveis - sem dúvida o principal - pela política, com todas as consequências. $O$ fortalecimento da autoridade aumenta a rebeldia ao domínio português. Como reconheceu Capistrano,

"se quiséssemos designar cada século da nossa história por um epíteto aproximado, caberia o de pernambucano ao XVI, o de baiano-paulista ao XVII, o de mineiro ao XVIII".

O que não significa, é claro, que a Capitania central esgote a história brasileira da época - tambem a da definição do território, com a: guerras no Sul por limites -, mas apenas que foi seu eixo e polo.

A expressão "polo de desenvolvimento" ou "de crescimento" tornou-se comum entre economistas, quando se colocou o estudo das áreas subdesenvolvidas. Cunharam-se então conceitos que tiveram ampla circulação, como o de centro-periferia, dominação, matriz da 
idéia atual de dependência. Certos núcleos são reconhecidamente dominantes, exercem influências sobre outros, cujo progresso ou estagnação resulta do sistema em que se integram e cujo eixo é o centro, ou polo, para o qual tudo converge e do qual saem as linhas diretoras de outras áreas. O conceito foi sendo refinado e a economia tem hoje boa técnica para medir os seus efeitos, no centro, centro-periferia, áreas dominantes e dominadas, seja no plano universal, entre continentes ou nações, ou, dentro das nações, entre as diferentes unidades. Ainda nas unidades político-administrativas menores é possivel reconhecer esse relacionamento.

Pedimos emprestado à economia a noção de polo de desenvolvimento, refinada por vários autores (como François Perroux, talvez quem mais a tenha usado e aprimorado), mas, evidentemente, o sentido que the atribuimos é outro, mais amplo e menos determinado. Entendemos por polo um centro irradiador de influências, que acaba por atingir ou mesmo mudar outras áreas. Elas são alteradas em sua natureza pelo que se verifica no eixo que domina, ainda não mantenham contato direto com ele. E processo sutil e de impossivel mensuração, de modo que a palavra "polo" não tem o sentido severo da economia e que provoca enorme número de trabalhos, às vezes de boa qualidade e esclarecedores de realidades especiais.

Quando se diz que Minas é o polo do desenvolvimento no século XVIII o que se deseja fixar é que é o núcleo mais importante, configurando fisionomia determinada e que acaba por exercer influência nas demais. Assim é que sua economia é original - não é agrícola, mas mineradora; o vulto dessa economia perturba as demais atividades, que sofrem alterações para que funcione melhor o labor de obtenção de ouro e pedras; verifica-se uma corrida de gente para o centro, de modo que há ameaça de despovoamento de outras Capitanias; forma-se, de um instante para outro, unidade político-administrativa importante, populosa e rica, que atrai as atenções e recebe logo título, status e organização que outras levaram decênios a receber. A sociedade das minas se distingue pelo carater de luta permanente, de aventura, que todos querem o enriquecimento, com o desrespeito das normas fixadas. Sua História é interminavel série de rebeliões, em que se manifestam índios contra o invasor, negros contra os senhores, bran(i)s - portugueses ou não - contra as autoridades. História cruenta e de constantes sobressaltos, o que explica a pronta montagem da máquina administrativa. Do achado do ouro, na última década do século XVII, à instalação da Capitania de Minas, em 1720, há menos de trinta anos.

E a necessidade de estabelecer os serviços do fisco, da justiça e da polícia que explica o rápido processo. E pela característica econô- 
mica mineratória, com todas as atenções nesse esforço, que resulta a criação de um mercado interno, uma vez que a área passa a ser o centro que homens de outras origens procuram para seus negócios, para a venda de gêneros alimentícios, tecidos, objetos de todo tipo, que ela, de acordo com a política metropolitana, apenas se entrega à busca de ouro e pedras preciosas. E o primeiro mercado nacional, que contribui para a ligação de unidades até então fechadas em si mesmas e que agora se abrem, pelo comércio, umas às outras. Daí dizer-se que Minas dá a primeira nota de integração nacional. No plano político, a existência da Capitania exige alteração das normas do administrador, que não pode continuar relativamente ausente, mas tem que montar a máquina administrativa com todas as suas peças.

E grande, pois, o interesse da unidade central e sobre ela se debruçam os historiadores. Notadamente os mineiros, que praticamente se resumem, no seu estudo, ao século XVIII, pelas singularidades que então se verificam, esquecidos que a região se projeta tambem nos séculos seguintes. Desagrada-nos essa atitude de concentração exclusivista em uma época, a não ser, é claro, no caso de monografias. Mais digno de reparo ainda é que, apesar de tudo, ainda há muito a ser visto, por falta de pesquisas extensas. E com pesar que se verifica a pobreza da historiografia: outras unidades menos importantes a têm mais rica, em fato pouco abonador dos cientistas sociais de Minas.

O que aqui se apresenta é apenas resumo de ensaio maior. Não trata do elemento econômico, desenvolvido naquele trabalho. Fragmento de análise de Minas no século XVIII, o presente deixa sem abordagem vários aspectos. O social, por exemplo. Em versão ampliada - esta é simples resumo da política - economia e sociedade são focalizadas. O que se apresenta vem a ser apenas o estudo da centralização política que se verifica no Brasil do setecentos, como projeção da existência de Minas. Polo de desenvolvimento do Brasil então, a Capitania afeta todo o sistema, sobretudo na organização política. Só a esse aspecto é que vamos fazer referência com minúcia, portanto. O mais fica para outra versão deste trabalho, bem mais ampla, por tentar visão global de Minas e do Brasil no século XVIII.

\section{Centralização politica.}

A administração do Brasil português é caso de transplante de instituições que se criaram e se desenvolveram na Europa durante séculos. Na aventura do expansionismo, em que Portugal se adiantou às demais nações, no primeiro momento o Brasil foi peça destituida de importância, uma vez que o colonizador era pequeno em número e 
recursos (1.122.112 habitantes em 1527). Tinha de empenhar-se, pois, no Oriente, que a India era o que havia de mais cobiçado. Havia ainda a África, ilhas do Atlântico e do Indico. Poucos portugueses vieram, em condições nem sempre conhecidas, bem como raras providências oficiais foram tomadas até a quarta década. Desde o princípio, contudo, o Brasil despertou atenções: quando mais não fosse, pelo receio de perder as terras para franceses, ingleses e espanhois, Portugal inicia a colonização, com base na grande lavoura para abastecer os mercados consumidores. O interesse aumenta depois de 1640, findo o período filipino, quando a Metrópole tem que se organizar melhor. Desfizera-se o encantamento com o Oriente, o principal agora está no mundo americano.

Desde a primeira metade do quinhentos começa processo político-administrativo que oscilou entre a centralização e a descentralização, impondo-se ora uma ora outra, pelas necessidades do momento e indispensáveis correçōes de excessos praticados. Já no começo da quarta década do século XVI instala-se o sistema das Capitanias, que fora experimentado em ilhas, quando se concedem áreas a grandes senhores, com carater de hereditariedade, para exploração. $O$ governo descentralizado é o que se estabelece, quando a Coroa abdica de muitas de suas prerrogativas, delegadas a agentes de confiança. A experiência deu pequenos resultados, e pouco depois, em 1548, ensaia-se a centralização, o chamado governo geral, com sede na Bahia. Não é intenso o seu exercício, que a extensa superfície o impede: as Capitanias continuam, apenas com poderes diminuidos.

Com a vinda de Tomé de Souza, há organização mais rígida, tudo em obediência ao Regimento que traz e às normas que fixa. Era uma espécie de Constituição, anterior à idéia de constitucionalidade. Já antes, nas cartas de doação de Capitanias, estabeleciam-se direitos e deveres. Não se conhecia o pais, havia apenas tribos dispersas e pequeno número de colonizadores e se montava a máquina do Estado. $E$ natural que o funcionamento fosse deficiente. Digno de realce, porem, é o intento de administrar, o Estado presente. Em 1572 divide-se o governo em dois - um na Bahia, outro no Rio de Janeiro, para logo depois, em 78, voltar-se à centralização na Bahia. A experiência é repetida entre 1608 e 12 e 1659 e 62 . Divisão importante é a de 1621 , quando se estabelecem dois governos, com amplas e reais jurisdições: o Estado do Brasil, com centro na Bahia, e o Estado do Maranhão, centro ora em São Luis, ora em Belem.

A precariedade da Metrópole, dispondo de poucos homens e recursos para o Império, bem como a extensão do território, explicam as dificuldades do poder público e seu alcance reduzido nos primeiros 
decênios. A ordem é mínima, verificando-se mesmo a completa desordem, que a colonização é aventura em que as regras se afrouxam. Assim é sobretudo nos dois primeiros séculos, continuando ainda depois, apesar da montagem da máquina repressiva. $O$ assunto tem sido objeto de muita análise de historiador, sociólogo, político. Não vem ao caso discutir o tão discutido tema de caracterizar a organização como feudal. Parece-nos ocioso o debate, notadamente após os estudos de história econômica, que revelam que a empresa foi sempre eminentemente capitalista.

Configura esse carater o fato de a economia ser voltada para fora, produção para o exterior. O traço da economia colonial é exatamente a obtenção de gêneros em grande escala, para abastecer os centros consumidores - o Ocidente europeu. Daí a monocultura, em grandes propriedades, que só assim se obtem lucro no comércio da época. O latifúndio cria sociedade de poucos senhores, que domina massa de escravos: o proprietário é poderoso, tem a riqueza básica, que é a terra; alem da força econômica, dono de extenso território de população submissa, tem prestígio político. Na vida do século XVI e metade do seguinte é elemento sem contraste, que a administração é tênue, pouco se faz sentir a autoridade. A coleta, a cana, o açucar, o fumo, o algodão consomem seus esforços. Não há perspectivas para a pequena propriedade, o colono livre e modesto, que se dedica à lavoura para subsistência. O poder público só aparece mesmo na sede do governo, nos núcleos urbanos - raros e pobres - , em que há funcionários. Os senhores rurais é que contam, organizam o poder nas Câmaras que elegem, em que se elegem ou aos seus. A autoridade se omite, que é mínima, tendo nesses senhores agentes de seus desígnios - produção econômica, devassamento do território, defesa contra possíveis invasores. A distância explica o afrouxamento da ordem, a ausência de lei. Como escreveu o culto e cauteloso Vilhena, em 1802, já no período de desgaste do domínio português,

"não é das menores desgraças o viver em colônias, longe do soberano, porque nelas a lei que de ordinário se observa é a vontade do que mais pode, se bem que mais em umas que em outras".

Na segunda metade do século XVII Portugal recomeça sua existência autônoma, livre da tutela espanhola, sob a dinastia de Bragança: fortalecida no poder, tende ao absolutismo, que realiza no século XVIII. Consuma-se a expulsão do flamengo - obra mais brasileira que portuguesa. A Metrópole percebe que, desfeita a ilusão da India, o que tem de mais precioso é o Brasil. Intensifica-se a migraçåo para 
o continente americano. Apesar de crises eventuais, com a concorrência de outros no fornecimento de açucar, o comércio dos portos aumenta, com mais impostos e funcionários. Para cúmulo do processo, descobre-se o esperado ouro na última década. Mais intensa ainda se faz a migração para o Brasil, a ponto de assustar a Coroa, que começa a criar-lhe dificuldades e até a proibi-la, como se vê em medidas de $1646,60,67,1709,11$ e 20 , medidas que apenas acentuam o que consta das Ordenações Filipinas, cujo Livro V, no título 107, fala

"dos que sem licença del Rei vão, ou mudam à India, Mina, Guiné, e dos que indo com licença, não guardam seus Regimentos".

A reiteração de medidas proibitivas é a prova de que eram inúteis, não tinham observância. A vinda contínua explica a presença alta de portugueses durante a fase de domínio (e mesmo depois, como se sabe). Procuram sobretudo Minas. Muitos voltam à pátria, enriquecidos, divulgando-se em Portugal a figura do "mineiro", objeto de certo folclore (como depois da Independência a do "brasileiro"); eles investem em propriedades e ostentação o que ganharam com trabalho, ou com a sorte e talvez com artifícios pouco honestos. Alexandre Herculano fala de "mineiros" e "brasileiros" em mais de um de seus escritos.

Terá sido bem maior o número de portugueses na América que de espanhois, embora o Império espanhol fosse mais extenso. Já na época o fato não escapou ao informadíssimo Adam Smith, que o assinala na parte que dedica ao sistema colonial do clássico $A$ riqueza das nações, em 1776. Para defender seu domínio, o governo aumenta os monopólios e proibições. Cria as Companhias de Comércio, muito mais para a expoliação que para o fomento, como se vê desde 1647 . Como consequência, aumenta o quadro burocrático, de comerciantes, de mineiros.

O emigrante vem sobretudo para o comércio, para as cidades, em movimento espontâneo. Para o labor agrícola houve política orientada pelo governo: são os que vêm para colonizar, em geral de ilhas - como os "casais" dos Açores -, para o Pará em 1673, depois para o Rio Grande do Sul e Santa Catarina, a fim de povoar terras distantes, incorporando-as de fato. E programa do administrador esse movimento, ao contrário do outro, que se tentou muitas vezes coibir, ainda que sem êxito. Agora, não é mais só o senhor rural, mas tambem o dono da riqueza movel, em burguesia incipiente. E natural a oposição entre os dois grupos, cujos interesses são diversos e cujas lutas são fendas no sistema. Burguesia de início apenas portuguesa, 
passa a ser em parte brasileira. Se o governo a favorece com privilégios, acaba por ser entrave a seu crescimento, pois não é bastante forte para defende-la ante concorrentes, como se vê no fim do século XVIII e início do seguinte. No período bragantino, o poder do senhor rural é afetado, já não é mais o único a eleger e ser eleito: tem que partir o domínio com outros grupos, em Câmaras municipais crescentemente enfraquecidas ante prerrogativas do governo. Assim em Pernambuco, com a vitória de Recife sobre Olinda, nas minas, em São Paulo, no Rio, na Bahia, no Maranhão, Pará. Cresce o quadro burocrático, nas funções de polícia, justiça e fisco. O século XVIII vê fortalecer a autoridade, o Estado.

Se foi forte o patriarcalismo, o particularismo dos senhores, como se sabe por muito estudo feito, o certo é que houve sempre o Estado, a Coroa jamais se omitiu. Entre os analistas do problema, queremos destacar Raimundo Faoro, em Os donos do poder, livro de 1958, y 1 e assinala relativa ordem no primeiro século, no plano das relações entre autoridades e indivíduos (os procedimentos irregulares não contam), na harmonia entre colonos e administradores. Para ele, a agitação dos sertões começa por volta de 1600 , devida não a agricultores, em regra pacíficos, mas a

"outra capa social, para qual a propriedade rural era secundária, e que assentava seu poder no séquito e na clientela militar, distinguindo-se pelos feitos contra o índio e na obra de devassar o sertão bruto".

Alem dos administradores e agricultores, havia os caudilhos, a "aristocracia militar", que provocava a turbulência dos sertões, animados pela própria autoridade, para conter índios ou escravos rebeldes, devassar o interior ou buscar pedras e metais preciosos. Era outra forma de delegação do poder de parte do representante do rei, impossibilitado de exercer todos os papeis. Explica-se assim a existências das bandeiras, dirigidas por senhores audaciosos e que podiam montar um séquito militar. Eram estimulados pela própria Coroa, que os animava às lutas nos sertões, para pacificar índios e escravos ou procurar prata, ouro e pedras, como se conhece por inúmeros documentos, inclusive cartas do Rei de incentivo à ação de potentados, em geral paulistas (caso de Fernão Dias Pais, entre outros). Nos sertões são senhores, cometem os atos que desejam, mesmo o arbítrio. A administração os estimula, a princípio, depois é o desentendimento.

Como assinala o historiador-sociólogo, 


\begin{abstract}
"notam-se duas fases da política real: primeiro, o estímulo franco, depois a simples transigência, suportando arranhões da autoridade. Chegaria o terceiro momento, por volta do fim do século XVII, de aberto desentendimento, com o conflito entre a voracidade fiscal da Coroa e a privatização do poder dos potentados. Ocorre a ruptura com a descoberta das minas e o desenvolvimento da riqueza pastoril, no Sul, e com o grande valor da atividade açucareira, ao Norte".
\end{abstract}

E o momento das lutas, que se multiplicam. As mais importantes foram as dos emboabas, em 1708-10, em Minas, e as dos mascates, em 1710-1, em Pernambuco. Verificam-se choques sangrentos entre os agentes do rei e os chefes rurais ou dos sertões, antes tolerados e até estimulados em seus arbítrios, como se observa nos choques entre os grandes senhores de Olinda e os comerciantes de Recife, no episódio pernambucano, ou entre os primeiros descobridores de ouro e os que acorrem às minas na disputa de terras, ou entre os que se supõem donos e as autoridades que desejam a paz e o pagamento de tributos, no episódio mineiro.

Necessidades de ordem e impostos explicam o crescimento da máquina da justiça e do fisco. O Estado tem que se organizar, para melhor impor-se. Cresce a centralização, o fortalecimento das autoridades, que a época é de absolutismo. Deve ser assim nas Colônias, como o é nas Metrópoles: a ideologia dominante o consagra. E o século XVIII vai ver a montagem administrativa mais eficaz, não sem lutas. O vitorioso é o Estado, impondo-se aos poucos. E claro que não poderá vencer de todo: os sinais de patriarcalismo atravessam o século, projetando-se no Brasil livre na monarquia e na $\mathrm{Re}-$ pública, aparecendo até em nossos dias em pontos mais distantes, de fraca ou nula urbanização.

Em linhas gerais, a análise de Faoro é exata. Daí o aproveitamento dela, uma vez que assim se explica a mudança da política do século XVIII. Em grande parte, é modo de ver que coincide com o de Caio Prado Junior em seu primeiro livro, Evolução política do Brasil, de 1933, apesar das diferenças de enfoque, seja no material considerado, seja no instrumental interpretativo - Caio com base em Marx, Faoro em Max Weber. São colocações que nos parecem felizes, pelo relevo que concedem ao Estado. Deve-se o mérito da formulação a Caio Prado Junior, autor pioneiro. Há analistas de diverso enfoque, exaltando antes o que houve em todo o período português de atomização do poder, de vigor das pequenas unidades.

O melhor exemplo é o de Oliveira Viana, ao longo de todos os seus livros, que representam contribuição esclarecedora do processo, 
desde 1920, em Evolução do povo brasileiro. Para ele o poder público, mesmo no tempo dos Vice-Reis, foi sempre enfraquecido, notadamente por fatores geográficos, que impediam seu real estabelecimento. Para o sociólogo, pela distância e força dos potentados locais,

"chegada a esse ponto a desintegração do poder central da Capitania, já não se pode falar mais da fragmentação do poder, nem mesmo da pulverização do poder: está-se já agora diante de uma verdadeira dissolução do poder".

Há muito de real na análise, mas não se pode aceita-la, que não tem em conta o sentido geral da política. E o que se vê, aliás, do próprio texto do autor, quando verifica a força dos capitães-generais no Centro-Sul,

"onde, depois da guerra dos emboabas, a caudilhagem 6 batida pelo poder central de uma maneira definitiva".

Oliveira Viana exagerou antes como agora, uma vez que a caudilhagem não é batida de "maneira definitiva", que continua a existir em momentos na vida de Minas e outras faixas. A afirmativa categórica citada em primeiro lugar é conclusão que tira de carta do governador de São Paulo sobre a impossibilidade de conter os potentados, de excessos particularistas cometidos. Se é ante essa afirmativa que chega a falar em "dissolução do poder", como falar que a caudilhagem fora definitivamente batida? A observação procede, mas só em parte: a guerra dos emboabas arma o poder central, de modo a criar novo conceito de Estado, mas ele não tem vigor necessário para conter no todo e de vez a força dos senhores.

Tambem de realce do particular é a posição de Gilberto Freire, notadamente em Casa Grande e Senzala, de 1933, em que apresenta a obra portuguesa na América como

"não do Estado colonizador, sempre sumítico em Portugal, mas de corajosa iniciativa particular",

em tese contestavel, pois se sabe de seu carater absolutista e da grande capacidade de iniciativa da Coroa sob a dinastia de Aviz. O sociólogo tende antes para os aspectos que lembram o feudalismo, embora reconheça nele

"algo de típico (...) pois sofreu restrição ou mesmo refração num Portugal influenciado pela Africa". 
O certo é que fala, em mais de uma passagem, nas "tendências feudais", pelo particularismo em que prazeirozamente se detem ao longo de toda a sua obra - o que não se dá por acaso.

$O$ auge da centralização verifica-se quando a Metrópole está sob a direção de Pombal, que se orienta sob o signo da unidade, submetendo a nobreza, os fatores dispersivos, para engrandecimento da Coroa . O ministro teve domínio sem contraste por mais de vinte e cinco anos (1750-77). Sua obra não é mero empirismo, pois obedeceu a toda uma filosofia, que se inscreve na linha do déspota de luzes, inspirada no pensamento do mercantilismo.

A presença mais viva do administrador, em padrões severos e até arbitrários, provoca a reação contrária, como é normal. Daí as rebeldias de escravos e homens livres. Se aquelas já vinham de antes, essas eram episódicas e adquirem vigor no começo do século mascates e emboabas - , continuando ao longo de todo o período, para adquirir conotação mais curiosa no último decênio, com os movimentos de conjurações - a mineira, a carioca e a baiana, depois nas lutas pernambucanas de 1801 e 17 . O rigor da autoridade leva às manifestações em favor da liberdade, prenunciando a superação da tutela portuguesa de certas áreas, em protestos que costumavam ser políticos (caso mineiro, por excmplo), às vezes com carregada coloração social (caso baiano, sobretudo) - presença no Brasil, como no resto da América, do movimento de idéias que cresce na Europa e chega à afirmação no episódio francês de 1789 , como chegara antes à independência de um pais do continente, no episódio norte-americano de 76. O Brasil crescera em população e problemas, pela deficiência de suas produções e impossibilidade de ve-las defendidas no comércio quando em rivalidade com espanhois, franceses e ingleses (caso dos couros, açucar, algodão e fumo), por fraquezas, timidez ou falta de entendimento da Metrópole. Portugal, cuja economia se funda no Brasil, não é bom intermediário.

Brasileiros de diferentes pontos, de grupos dominantes - agricultutores e comerciantes -, sentem que a Coroa não pode defende-los. A ideologia do iluminismo tem adeptos entre portugueses e brasileiros, gente do governo e intelectuais, agricultores, comerciantes, mineiros. Pensam em termos do pais, querem a sua riqueza e engrandecimento, para melhores negócios e poder, ou para a sua afirmação como unidade livre. Vinha de antes o sentimento de ser brasileiro, nacional, ante o português, europeu, estrangeiro. Talvez mesmo no século XVII existisse, quando da expulsão do flamengo. Como era vivo no fim do setecentos, na época das conjurações. O grupo que tem consciência de que é preciso adquirir autonomia cresce no co- 
meço do século XIX, ante as dificuldades locais e a crise generalizada do colonialismo. E integrado mesmo por portugueses que têm aqui interesses e reconhecem a debilidade da Metrópole. Essa corrente fará a independência, em episódio singular do mundo americano, pela presença de um príncipe. $O$ que já escapa à análise aqui. Se o lembramos é que é o coroamento do processo de desagregação do sistema colonial, em que Portugal e Brasil repetem o mesmo que Espanha e várias unidades da América.

Impõe-se caracterizar o que foi o Estado no Brasil, ao longo do século XVIII. Houve a centralização política, manifesta sobretudo em Minas, na qual a tendência se extrema, pois é ditada principalmente por essa área, que se torna o eixo da política no período. Em Minas é mais severa a nota centralizadora, como se vê na montagem de rígido aparelho tributário e de justiça. Há mesmo parte em que se atinge a plenitude do rigor - o Distrito Diamantino. Daí as vicissitudes da história da Capitania, mais ponteada de lutas que qualquer outra, exatamente por ser aquela em que o poder mais se exerce.

Houve a centralização política, imposta pela Coroa, mas não a centralização administrativa, que a Metrópole sempre reconheceu as peculiaridades locais, não vendo o Brasil como um todo, mas em suas especificidades. Esse reconhecimento explica a plasticidade e alguns êxitos do administrador. Quando se fala em centralização política, portanto, o que está em jogo é unidade para servir à Coroa, não a centralização da administração, que nunca existiu nem foi desejo da autoridade. Não se confunda, pois, o centralismo político com unificação política, ou centralismo administrativo. Preocupação centralizadora, com a direção de Lisboa, às vezes partindo da Bahia ou do Rio de Janeiro. Centralização política com base em Portugal, não centralização administrativa. Visava-se preservar o todo, mas não se chegou à unidade administrativa, que a Coroa estava convencida que não teria eficiência. Não se continuou, pois, ao longo do século, o particularismo anterior, em que senhores é que mandavam, como delegados. Se é possivel ainda percebe-los em todo o pais, é que a organização social por vezes o exige e a geografia o explica, como se dá, em escala cada vez menor, nos séculos seguintes, mesmo hoje. Agora, no setecentos, é a vez do poder público, que se apresenta sobre setores administrativos maiores ou menores, sem nunca perder de vista, no entanto, que se trata de algo que é da Coroa, constitui o Estado. E nesse sentido que se assinala a mudança de conceito, que se apresenta na teoria e na prática, verificada na presença do poder português em terras do Brasil.

Ainda que se aceite a colocação feita por Caio Prado Junior e Raimundo Faoro, como é nosso caso, não se deve deixar sem lem- 
brança que a tese não dispensa o relativismo. Até em Minas, de mais pronunciada atuação do poder público, percebe-se apreciavel sobrevivência do particularismo. Há lutas entre o representante da Coroa - chefe da Capitania - e os funcionários e o clero: os agentes do Fisco e da Justiça estiveram em constante atrito, como se vê em dezenas de casos (lembre-se a disputa entre o governador Luís da Cunha Menezes e o ouvidor Tomás Antônio Gonzaga). O mesmo se verifica quanto ao clero, agente de perturbação da ordem, em conluio com contrabandistas e sonegadores, ou contestatários do sistema, como comprova o envolvimento de muitos padres em todos os movimentos rebeldes. Demais, há as disputas entre as autoridades de Minas e as do Distrito Diamantino, cujas atribuições nunca foram bem delimitadas. Sem falar nas mais interessantes, que são entre governadores de Minas e de São Paulo e Rio de Janeiro.

Sobrevivência do particularismo, lembre-se que nos primeiros tempos os próprios governadores apelam para os particulares, aceitam seus favores, que devem ter contrapartida: assim foi com o potentado Pascoal da Silva Guimarães, que recepcionou Antônio de Albuquerque; ou Henrique Lopes, que fez o mesmo a Assumar. Ainda depois de 1720 , quando o governo é mais organizado e rígido, o fato se verifica, como se viu com João Rodrigues de Macedo, o dono dos contratos que não pagava o devido, construtor da Casa dos Contos, que teve acertos suspeitos com mais de um governador, o que lhe terá evitado o processo na conjuração de 1789 , da qual foi evidente participante. Mais de um documento atesta o quadro: o Conde de Bobadela, em sua conhecida Instrução e Norma, de 1752, explicita bem a situação, referindo-se aos "potentados de Pitanguí" que se rebelam à autoridade: "sombra da forma antiga das minas" (devia pensar em Manuel Nunes Viana e Pascoal da Silva Guimarães). Há dezenas de casos de turbulência, como se lê na História média de Minas Gerais, de Diogo de Vasconcelos, no admiravel capítulo "Motins do sertão". Há amotinados não só no sertão, mas até nas cidades, até em Vila Rica. O fato deve ser referido, confirmando a impossibilidade do exercício pleno do poder. Não se pode dar razão, no entanto, às teses de Oliveira Viana e Gilberto Freire, antes citadas. O que importa é o sentido geral, configurador da política, que afirma o poder público mais que o particular.

Como se vê, o fortalecimento do Estado no Brasil resulta principalmente da atuação de Minas, área que só é integrada no fím do século XVII. Descobre-se o ouro na última década e logo começa a sua história, de intensa movimentação. A desordem inicial conduz à guerra dos emboabas: para impor disciplina o governo cria a Capitania de São Paulo e Minas do Ouro, em 1709. Continuam as disputas, pela fragil máquina administrativa: daí o levante de Vila Rica, que 
leva ao sacrifício de Filipe dos Santos, em 1720. Com a ameaça constante, a Coroa procura armar de melhor forma a administração, criando em 1720 a Capitania de Minas Gerais. Nenhuma outra teve desenvolvimento tão rápido. Ela nunca foi de donatário, coisa particular, mas sempre entidade pública. E é para dirigi-la que se organiza com severidade o poder português, fortalecendo o Estado no Brasil, como se viu.

$\%$

Ainda Minas como eixo.

Minas foi o centro da política portuguesa no século XVIII. Ela é que explica o processo político-administrativo de então. Por ser a área de economia mais sedutora, as atençōes se voltam para o interior, com devassamento e ocupação mais rápida que as outras unidades, em processo original. Região rica no início e que precisava de contatos para complementar suas necessidades, estabelece vínculos com o Norte e o Sul, para os gêneros de que carece para alimento, vestuário e tudo mais. Contribui para o primeiro instante de integração nacional, por apresentar mercado interno, até aí desconhecido. Funciona, pois, como polo de desenvolvimento, com projeções nos vizinhos. $O$ destino do Sul, São Paulo, Rio, Bahia e mesmo do Nordeste é condicionado por essa originalidade das primeiras décadas. Muito que se verifica resulta do que se passa nas terras mineiras, o que permite afirmar que elas são o centro da história do Brasil ao longo do século XVIII, cuja política geral está em torno de suas peculiaridades e da questão de fronteiras, com a delimitação feita nos Tratados entre Portugal e Espanha, que levam mesmo a intermináveis lutas armadas. E até para as lutas Minas contribui, seja pelo financiamento - aí é que se faziam as mais altas arrecadações do fisco —, seja por tropas enviadas. A importância do ouro e as questões de fronteiras é que explicam o deslocamento do eixo do Nordeste para o Sul, evidenciado na transferência da Capital de Salvador para o Rio de Janeiro, em 1763.

Encarando agora o caso de Minas desligado do nacional, tem-se que sua História apresenta maior interesse exatamente no período. Explica-se assim que os estudiosos se detenham preferentemente nele. Apesar de tudo o que já se escreveu, há mais aspctos a serem esclarecidos, que o conhecimento é precário, por certa insuficiência na pesquisa, como se lembrou antes. Minas atrai o estudioso pela economia e pela política, como tambem pelo processo social. Como se sabe, sua sociedade se distingue da de outras áreas. Nas agrícolas, impöe-se a dicotomia de senhores e escravos, com mínimas possibilidades para os grupos médios. Que se desenvolvem inicialmente em Minas, pela diversificação econômica que leva a uma agricultura de subsistência, a 
atividades artesanais e manufatureiras, a comércio intenso, que tudo tem que ser comprado. Como não há a auto-suficiência das fazendas, o comerciante é indispensavel. O mesmo motivo - economia mineratória - explica o processo de urbanização, em Minas mais intenso que no resto do pais. E nos núcleos urbanos que se verificam as trocas, o comércio, as festas religiosas e profanas, vivem os funcionários da Coroa. Economia original configura sociedade que é tambem original.

A Capitania atrai ainda pelo artístico, quando se vê em suas terras, na segunda metade do século, com a mineração decadente e a pobreza generalizada, intenso movimento intelectual e criador. Até então nada se verificara de equivalente no país. Desenvolve-se rica literatura, que dá alguns nomes que ainda hoje se projetam, cujas obras sobreviveram, notadamente poetas. Cria-se um estilo de artes plásticas, com arquitetura realmente soberba, que se manifesta em inúmeras igrejas, casas particulares e alguns edifícios públicos. Se não se distinguem pela monumentalidade - as igrejas baianas são superiores -, distinguem-se pelo refinamento. Tão rica como a arquitetura é a escultura, que produz obras-primas que podem ser confrontadas com 0 que de melhor já se produziu. Não queríamos citar nomes, mas não se pode omitir o de Antônio Francisco Lisboa, o Aleijadinho, arquiteto e escultor que é o maior artista brasileiro, talvez não apenas da época, que nenhum outro o iguala antes nem depois. Enfaticamente, pode-se avançar que é mesmo a figura maior das artes do mundo americano. Tambem a música se desenvolveu, como se sabe por pesquisas recentes. Só há poucos anos se revela o universo musical mineiro, que contou com dezenas de compositores, alguns dos quais são consideráveis. Cria-se, desse modo, todo um movimento artístico, em que a literatura, as artes plásticas e a música se conjugam, revelando afinidades estilísticas e todo um estado de consciência criadora que é o primeiro do pais, já com algumas características nacionais, embora suas fontes sejam em grande parte modelos europeus. A chamada "escola mineira", ou, mais impropriamente, o "barroco mineiro" é momento único no passado. E uma das razões a mais para o interesse do estudioso pelo período. Capistrano de Abreu estava certo ao chamar o século XVIII de mineiro.

Se insistimos tanto na proeminência da Capitania então, é preciso recusar certas projeções que lhe atribuem no plano externo. E o que se dá com a afirmativa de que o ouro brasileiro do século XVIII é o agente do capitalismo. E ir longe demais no gosto de buscar repercussões. Sombart é que o disse de modo veemente, em passagem de $O$ burguês, divulgada entre nós pela História econômica do Brasil de Roberto Simonsen. Ora, a economia já era então eminentemente britânica e há para o fato elementos mais ponderáveis, como a estabi- 
lidade política, a supremacia comercial com as "leis de navegação", as "leis dos cercos" que desenvolvem a agricultura e dispensam mão-de-obra, em crescimento econômico que será acelerado com o pioneirismo industrial que leva à supremacia incontrastavel do século XIX. $O$ ouro que Portugal deixou sair terá sido fator menor: mesmo sem ele a Grã Bretanha chegaria à posição de domínio - tese a ser comprovada por um exercício de counterfactual History, à maneira da escola norte-americana.

Revela-se, pois, em Minas, processo singular pelo muito que produziu. E essa totalidade, que constitui cultura de notas bem típicas, que criou escola, estilo, modo de ser, psicologia que se distingue no quadro nacional, projetando-se no século seguinte e no presente. Já se disse que a cultura brasileira é um arquipélago constituido de muitas ilhas, ou que é uma cultura que se caracteriza pela soma de algumas sub-culturas. Minas é uma delas. Se não é a mais interessante, na perspectiva global, foi a mais interessante no século XVIII, quando se constitui e chegou à plenitude, em momento que não conseguiu repetir até agora e que repercutiu em todo o processo brasileiro. Seu estudo sumário, aqui, é pelo fato de ser ela o centro de tudo então, polo irradiador de influências, principal elemento a configurar o Estado português na América e cuja natureza se procurou esclarecer.

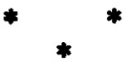

FRANCISCO IGLÉSIAS - Nasceu em Pirapora, Minas Gerais. Fez o curso de Geografia e História na Faculdade de Filosofia da Universidade Federal de Minas Gerais, em Belo Horizonte, diplomando-se em 1945. Professor de História em vários Colégios, dedica-se atualmente apenas à Universidade $\mathrm{Fe}$ deral de Minas Gerais, na qual é liyre-docente de História Econômica Geral e do Brasil, na Faculdade de Ciências Econômicas. Ocupou alguns cargos de administração na Reitoria e é agora Assessor na parte de História em projetos da Fundação João Pinheiro. Participou de vários Congressos no Brasil e exterior, quase sempre com teses. Escreveu artigos e ensaios em jornais e revistas de Minas, São Paulo, Rio de Janeiro, ou do México. Publicou alguns livros: Politica econômica do governo provincial mineiro (Rio de Janeiro, Instituto Nacional do Livro, 1959); Introdução à historiografia econômica (Belo Horizonte, FACE, 1959); Periodizaçâo do processo industrial no Brasil (Belo Horizonte, FACE, 1963); História e Ideologia (São Paulo, Perspectiva, 1971); Breve História Econômica de Minas Gerais (Belo Horizonte, AC, 1972); História para o Vestibular (Belo Horizonte, Edi- 
ções Júpiter, 1973); História Moderna e Contemporânea (Belo Horizonte, Edições Júpiter, 1975). Colaborou em livros, como História Geral da Civilização Brasileira (Tomo II, Vol. II Minas Gerais; Tomo II, Vol. III - Vida politica, 1848-68 São Paulo, Difusão Européia do Livro, 1964 e 67); La História Económica en América Latina (Vol. I - Situación de la Historia económica en Brasil; Vol. II - Bibliografia de Historia Económica en Brasil - México, Sep/Setentas, 1972). Prefaciou: Alberto Wanderley - Estudos de Geografia Econômica (Belo Horizonte, FACE, 1959); Celso Furtado - Formaçdo econômica do Brasil (Brasília, Editora da Universidade, 1963); Fernando Correia Dias - João Alphonsus: Tempo e Modo (Belo Horizonte, CEM, 1965); Lourival Gomes Machado - Barroco mineiro (São Paulo, Perspectiva, 1969); Lúcio José dos Santos - História de Minas Gerais e A Inconfidência Mineira (Bele Horizonte, Imprensa Oficial, 1972); Diogo de Vasconcelos - História antiga das Minas Gerais (Belo Horizonte, Itatiaia, 1974). 